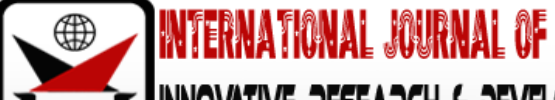

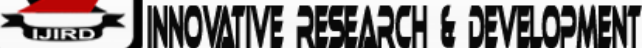

ISSN 2278- 0211 (Online)

\section{Redefining Corrupt Public Procurement Practices in Ghana Based on Stakeholders' Perception}

\author{
Benjamin Boahene Akomah \\ Lecturer, Department of Building Technology, Cape Coast Technical University, Cape Coast, Ghana \\ Gabriel Nani \\ Lecturer, Department of Building Technology, \\ Kwame Nkrumah University of Science and Technology, Kumasi, Ghana
}

\begin{abstract}
:
Government and public institutions procure diverse works, goods and services from different business organizations from time to time. These acquisitions are often perceived to be surrounded by corrupt practices and with this perception in mind, people have little or no trust in public institutions and public procurement processes. The paper seeks to identify the different forms of corrupt procurement practices to assist in the redefinition of the term. The study was conducted in two regions, namely: the Greater Accra Region and the Central Region. A field survey conducted included 120 respondents made up of contractors, opinion leaders, press men, industry professionals from public institutions and donor agencies. The study concludes by redefining corrupt procurement practice as: "the direct or indirect offering, giving, receiving, or soliciting of gifts or bribes, conspiracies among firms, or fraudulent practices that influence the procurement selection process or contract execution for personal gain."
\end{abstract}

Keywords: Redefining corrupt public procurement practices, forms of corruption, stakeholders' perception, Ghana

\section{Introduction}

Government and public institutions enter into countless number of contracts every year. These contracts are often for works, supply of goods or services. Whether they are works, goods or services contracts, there are laid down rules, regulations and guidelines that govern their procurement. The term procurement is a task that ensures that needs are adequately identified, sourced and managed (Chartered Institute of Purchasing and Supply (CIPS), 2005). Corrupt practices can take place at any point along the chain of the procurement process and influence the outcome. These practices have huge economic and social impact which can negatively affect development. According to Transparency International (TI) (2006), procurement of goods, works and other services by public institutions constitute about 15 to 30 percent of a country's gross domestic product (GDP). The organisation continued by saying that the percentages may even be higher than what is stated depending on the country under review. Rose-Ackerman and Søreide (2011) pegged public procurement for most countries between 15 and 20 percent of GDP. The percentage of GDP which goes into public procurement justifies why procurement activities must be taken seriously by all stakeholders.

There are a number of practices that are considered by professionals, contractors, donor agencies, opinion leaders and the press as corrupt practices in procurement. While some firms can talk about the experiences they have had interacting with public institutions, others may have witnessed certain actions or by their stimuli interpreted certain actions to becorrupt practices. Lindsay and Norman (1977) said perception is an assumption and classification of feelings by humans that produces meaningful understanding of the world around us. It can also be an interpretation of what is taken in and processed through human senses. This means that people who often talk about corruption in public procurement may have experienced, seen or heard of it and made their own conclusions. These conclusions are what create the bad images for public institutions. Whether we like it or not, the perceptions of people go a long way to question the integrity of public procurement in the country. What professionals and actors in public institutions have to understand is, perceptions of corruption or corrupt practices have a way of rupturing the trust of firms.

Fairness, transparency and non-discrimination are the three important principles in procurement and anything which plays down on these can affect the credibility of a procurement process hence the need to ensure a clean process (Gilbert, 2011) to achieve value for money. Corrupt practice constitute an abuse or misuse of one's delegated power whose end product is personal gain (Transparency International (TI), 2006; Seldadyo and Haan, 2006; World Bank, 1997). It is classified asa comprehensive concept that has the potential of impeding development if not curtailed (Aidt, 2003; Frøystad, Heggstad and Fjeldstad, 2010). Private firms and public servants engage in these practices because they believe their successes lie in bending the procurement rules (Harstad and Svensson, 2011). Corrupt procurement practices have harmful long-term economic implications and may influence transaction costs (Ocheje, 2001).Transparency International (TI) (20n6) ascerts that the value of corruntion can he as hioh as 40 to $50 \%$ of contract value 
Officials employed by the State to manage procurement activities in various public institutions usually do behind the scenes business with contractors and suppliers. This practice is a breach of trust, professional ethics and leads to insider trading activities. The unethical working together, leads to information leakages and unjust competition among contractors and suppliers. This unprofessional collaboration creates dissatisfaction and defeats the principle of fairness in procurement. The partnership between officers and contractors is occasionally extended to project claims where contractors submit false or inconsistent claims and they are sometimes protected by public officers who have a mandate to detect and revise them. Another corrupt practice is the manipulation of procurement processes by high ranking public officers to favour a particular firm. This is done by modifying bidding strategies to alter the allocation of contract (Hui, Othman, Omar, Rahman and Haron, 2011; Burguet\& Perry, 1999). Thai (2009) postulated that many public officials see procurement activities as a means of achieving economic, social and other objectives. At contract implementation stages of construction projects, consultants may demand bribes in order to grant contract variations, approve time extensions, certify defective works or expedite wrongful payments (Osei-Tutu, 2010).

Conspiracies in procurement are real and cannot be underestimated. They are very complex and can come in many forms. Firms by agreement can divide a given procurement market into segments and concur not to compete in each other's segment (Heggstad, Frøystad and Isaksen, 2010). It is a practice firms engage in to enhance their profits. They make more money from clients than they should because of their schemes. Payment of bribes by firms to secure jobs is becoming a custom. Firms make unlawful payments with the intention of gaining favourable treatment from procurement officials (Cisar, 2003). According to Rose-Ackerman (1999), the prime motive for making an illegitimate payment to a public officer is to acquire an undeserved benefit. This undeserved gain constitute an act of corruption. The pervasive nature of corruption in public procurement in the country clearly indicates that there is something wrong with the management of procurement processes in public institutions. Djankov, Glaeser, La Porta, Lopez-De-Silanes and Shleifer (2003) argued that corrupt practices in procurement upsurge as a result of bad policies, incompetent professionals and lack of strict enforcement of procurement rules, regulations and guidelines by institutions.

Another disturbing issue that is negatively impacting public procurement is the interference by politicians. Politicians have become so powerful that they can sometimes influence procurement officers to bend the rules and regulations during the procurement process. When an official is instructed to act in favour of a particular firm, it is called order from above. This phenomenon accounts for the shoddy works done by contractors. Hui, Othman, Omar, Rahman and Haron (2011) stated that, where there is intrusion by politicians in government procurement, their associates win every job. In an instance where the cronies of politicians get the jobs, consultants have little or no power to call them to order even when they are doing something wrong. Many of the corrupt practices that take place in procurement happen between firms and institutional officers who have the mandate to protect public interest. There is a party who is always willing to give and another who is also always excited to take. The giver and the receiver are all in for a benefit and would do whatever they can to have their personal interests fulfilled.

\subsection{Statement of the Problem}

Corruption in public procurement in Ghana is pervasive and one would wonder if corruption is still a perception or a reality. It is among the many problems that modern Ghana faces as a country. The fact that procurement constitute between $15 \%$ and $30 \%$ or even in some cases higher of a country's gross domestic product (GDP) means corrupt practices would be inevitable in such a lucrative area (Transparency International (TI), 2006). If corruption can take that much, then people should not be surprised to see shoddy jobs or projects whose total cost are so high.

According to the (European Bank for Reconstruction and Development (EBRD), (2010) and the United Nations Commission on International Trade Law (UNCITRAL), 2008) corrupt practice is the "offering, giving, receiving, or soliciting, directly or indirectly, anything of value to influence the action of a public official in the selection process or in contract execution".

A lot of researchers in academia have tried to identify some actions which are considered corrupt procurement practices. However, expert stakeholders, opinion leaders and people from the press have never been considered in the definition of term. All known definitions were taken basically from the view point of funding and donor agencies. The paper believes by including the stakeholders identified above, a comprehensive definition can be formulated and may form the basis for addressing issues of corrupt procurement practices in Ghana.

\subsection{Bribery}

In Ghana, most people see bribery as pure benevolence but to classify something received as such, one must look at when such goodwill took place. What is anticipated after an action is what distinguishes benevolence from bribery (BenNer and Putterman, 2000; Lambsdorff and Frank, 2010). Andvig, Fjeldstad, Amundsen, Sissener and Søreide (2001) said "bribery is any payment (in money or kind) that is given or taken in a corrupt relationship". Rose-Ackerman (1978) stated that the motivation for paying bribes in public procurement is twofold. Whiles the first motivation is to obtain a benefit from an entity, the second is to evade cost. According to Argandona (2003), bribery is said to have taken place when the one making the payment makes a proposal. The magnitude and occurrence of bribery is dependent on the benefit available and the freedom at the disposal of public officers during decision making. It can also be determined by the riskiness of the act and the negotiating skill of the bribe payer (Rose-Ackerman, 1978; Klitgaard, 1988).

The payment of bribes in domestic public procurement is common and perpetrators do so in an organized and deliberate manner (OECD, 2007). Frøystad, Heggstad and Fjeldstad (2010) described bribery as the offering of money, goods or services to a public procurement officer in order to gain an undue advantage over competitors. Transparency International (TI) (2006), said firms pay bribes which are usually bigger in amounts. Such payments are normally given to 
principal procurement officers of entities to obtain unjustifiable decisions even when the firm has no right or claim to such a decision.

The selection of suppliers, consultants or contractors is generally influenced by government or superior procurement officers. This behaviour has led to distortions in resource allocation and talents. Bribery is illegal and the risk for such payments is the uncertainty of getting what is demanded. Nonetheless, honesty may also entail risk and uncertainty. In the Ghanaian procurement environment where bribery has become the norm, honest firms are often tempted to offer bribes for fear of losing out on certain contracts based on the perception that their competitors may have bribed their way through (Transparency International (TI), 2006).

This insalubrious activity has become a catalyst for extortion and agents would do anything to bend the rules to satisfy their interest (Khalil, Lawarrée and Yun, 2010). According to Burguet and Perry (1999) where bribery occurs, tendering strategies may be varied to distort contract allocation.

\subsection{Facilitation Payments}

Facilitation payments are smaller amounts firms usually pay to lower ranked officials to accelerate the processing of their documents and decisions which firms are legally entitled to (Transparency International (TI), 2006). This payment is a form of bribe and should be seen as such. It is a different subset of bribery referred to as backhander or grease payment. It is illegal in some countries. Apart from the fact that they are illegal, they are also unethical (Bunker and Carsey, 2012). It can be made to secure normal and non-discretionary acts from public officials who work on certain documents within procurement outfits (Nichols, 2009). TRACE (2009) stated that facilitation payments are made to motivate officials to carry out regular task they have been employed to perform.

\subsection{Kickbacks}

In large public procurement projects, kickbacks are usually coordinated by people who are related to parties involved (Campos and Pradhan, 2007). They are forms of negotiations which take place between two or more parties or groups, where commissions are paid. The term can also be a manipulation of the process in favour of a particular firm for a percentage or a fee. They are mostly taken in huge government purchases. The practice has the ability to influence both minor and major procurement decisions (Deloitte, 2012). Kickbacks are carefully planned, and therefore make it difficult to detect. The act is more often than not carried out in such a way that it leaves little or no trace. Hellman, Jones and Kaufmann (2000) argued that foreign firms are likely to pay procurement kickbacks than domestic firms if the procurement in question is internationally competitive.

\subsection{Embezzlement}

Andvig, Fjeldstad, Amundsen, Sissener and Søreide (2001) defined embezzlement as the stealing of state resources by procurement officials who have authorization from the state to administer them. It is a fraudulent appropriation of state or institutional resources by persons for their own use (Amundsen, Sissener and Søreide, 2000). It is a form of power abuse, which seeks to extract institutional or state resources (Amundsen, Sissener and Søreide, 2000; Andvig, Fjeldstad, Amundsen, Sissener and Søreide, 2001). The act can be initiated by one person but for large scale embezzlement, several people within an institution may be involved. It takes place in both private and public procurement settings (Andvig, Fjeldstad, Amundsen, Sissener and Søreide, 2001) because of the lack of political or institutional will to confront it head-on.

\subsection{Fraud}

A lot of fraudulent activities go on in procurement every day. These actions deprive States or institutions from enjoying the benefits of the numerous purchases they initiate. Fraud is costly and is becoming more sophisticated due to the rapid development in technology. Fraudulent procurement activities may come in many forms. They may appear either as misrepresentation or abuse of power. These activities can only be unraveled through careful studies and effective procurement auditing. Fjeldstad (1999) defined "fraud as an economic crime that involves some kind of trickery, swindle or deceit". Andvig, Fjeldstad, Amundsen, Sissener and Søreide (2001) claimed that, fraud usually involves manipulation or misrepresentation of information, facts and expertise, by public officials for their private gains. Campos and Pradhan (2007) identified tender rigging, splitting of procurement packages, collusion between suppliers or contractors, unjustified variation orders, unjustified single sourcing and wrongful certification and approval of goods, works or services and concealment of facts during procurement reporting as some of the fraudulent practices that take place in procurement. According to the U.S. General Services and Administration (GSA), (2012) "Auditors should design the engagement to detect instances of fraud and noncompliance with provisions of laws, regulations, contracts and grants agreements that can have material effect on the subject matter or the assertion thereon of the examination engagement".

\subsection{Conflict of Interest}

Conflict of interest in simple terms is a clash between one's public or institutional interest and personal interest (Reed, 2010) or the influence of one's decision by his personal gains. Hui, Othman, Omar, Rahman and Haron (2011) stated that, where the cronies of officials compete with other firms for the same jobs, they win everything. Conflict of interest therefore, is the manipulation of a procurement process with one's acquired knowledge to award contracts to favoured firms. Public officials will always do their best to ensure the success of their associates. Smith (2006) argued that the pursuit of financial or personal gain can push procurement officials to behave contrary to their professional ethics. 
According to Gilbert (2011) there are no guidelines for identifying conflict of interest in procurement. To avoid any conflict of interest situation, it is imperative for officials to willingly declare to refrain from issues of conflict of interest (Gilbert, 2011). Where undeclared interest prevents officials from properly performing their official procurement duties, they would be guilty of conflict of interest (Hardell, Walker, Walhjalt, Friedman and Richter (2007). Conflict of interest may not always be a present procurement subject. It may be an established case that existed in the past for a specific procurement where an official may have abused his office (Wensink and Maarten de Vet, 2013).

\subsection{Extortion}

Extortion negatively influences the quality of a procurement outcome. Both principal and junior ranked procurement officers obtain money or other valuable things from suppliers and contractors by compulsion, force or threats. According to Argandona (2003), this act is said to have occurred when procurement officers working for the State take the initiative. Khalil, Lawarrée and Yun (2010) said the activity is more severe when the incentive for extorting is dependent on soft information or when the officer in charge of decision making has a better bargaining power to negotiate for unlawful payment. Officers who have little or weaker outside opportunities usually result to extortion. According to Khalil, Lawarrée and Yun (2010), the practice is not good because it discourages good behaviour. Klitgaard (1988) views extortion as a harmful form of corruption which brings about inefficiencies in procurement.

\subsection{Favouritism/Nepotism/Tribalism}

Favouritism kills competition. It is said to have taken place when a contractor or supplier is given a generous treatment at the expense of others. Svensson (2005) defined nepotism as favouritism shown to family members, members of the same tribe or friends. Many contracts end up in the hands of friends and relatives. Favouritism takes place because officers of public institutions and politicians have power and access to State resources and decide on how such resources should be distributed. Procurement officers usually use the power given to them to favour firms owned by their allies for their personal interest (Andvig, Fjeldstad, Amundsen, Sissener and Søreide, 2001). Hyytinen, Lundberg and Toivanen (2006) stated that about $61 \%$ of the times lowest evaluated tenders do not win contracts because of favouritism, nepotism or tribalism.

\subsection{Abuse of Discretion}

Procurement systems are not watertight and airtight, and can therefore be vulnerable to discretionary abuse (Myint, 2000). The failure of procurement officials to consider procurement laws, rules and regulations, or the irrational departure from the processes and procedures or practice amounts to abuse of discretion (Farlex Incorporated, 2013).

Every procurement decision is an opportunity for loss of public or institutional funds through corruption or incompetence. The challenge in regulating a procurement process is how best issues of subjectivity can be minimised to satisfy both public and institutional needs. Lambert and Sonin (2006) said the extension of tender submission deadlines can amount to abuse of discretion if such extensions cannot be justified. It was explained that, unjustified time extensions are granted by procurement entities to assist favoured firms to readjust their offers. Rose-Ackerman (1978) and Klitgaard (1988) proposed a reduction or complete elimination of discretionary powers given to procurement entity heads to help reduce corruption.

\section{Research Methodology}

The study employed survey research method. The research started with a comprehensive literature review to identify corrupt procurement practices. The literature review helped to generate a list of corrupt procurement practices which was authenticated by three procurement practitioners for relevance and feasibility. The authenticated list was structured into a questionnaire on a five point Likert scale ranging from 1 to 5 . Where 1 represented a factor that strongly disagreed and 5 represented a factor that strongly agreed. The questionnaires were thereafter distributed to respondents to solicit their responses. Respondents were asked to tick only one box on a row for each choice provided.

The field survey included 120 respondents made up of 35 professionals, 32 building contractors and 31 road contractors, one representative each from two donor agencies with focus on procurement, 10 opinion leaders and 10 press men with a certain knowledge in procurement. A total of 120 questionnaires were distributed to the various categories identified above. Purposive sampling technique was used for the selection of professionals from public and private institutions and the two donor agencies. Contractors, opinion leaders and press men on the other hand were selected using snowball technique. The snowball technique was used because the elements in the population could not be identified individually by the researcher and had to depend on identified contractors, opinion leaders and press men to reach others (Kumar, 1996). One hundred (100) questionnaires were completed and returned by respondents. This number represents a response rate of $83.3 \%$.

\subsection{Critiquing of New Definition}

In order to provide an acceptable definition for corrupt procurement practice, the definition that was generated out of the study after data collection and analysis was sent to (4) directors to critique. The (4) directors were purposively selected from (4) Anti-Corruption Agencies in Ghana, namely; the Commission on Human Rights and Administrative Justice (CHRAJ), Ghana Anti-Corruption Coalition (GACC), the local chapter of Transparency International (TI): Ghana Integrity Initiative (GII) and the Economic and Organised Crime Office (EOCO). The (4) agencies were selected because of their expertise in fighting corruption. The directors were selected because of the insight they have in corruption. Moreover, they represent these institutions and are accountable for whatever happens in their agencies. The researcher 
went first to the offices of these directors to build the needed rapport and afterwards handed over the critiquing sheets to them. After the time given by the various directors elapsed, the researcher went round to collect the critiquing sheets. According to Boswell and Cannon (2012) research critiquing is a careful, critical appraisal of the strengths and weaknesses of a research study, logical links, meaning and significance. Polit and Beck (2004) explained that, the purpose of research critiquing is only a mechanism to provide feedback and not a fault finding exercise. The critiquing exercise was therefore carried out to assess the appropriateness, adequacy, completeness and conciseness of the new definition. The new definition generated after data analysis was sent to the (4) directors to criticize it. Based on the comments and issues raised by the (4) directors, the definition was modified. The modification was necessary to ensure the appropriateness, adequacy, completeness and conciseness of the definition. The final definition was thereafter sent to critics for acceptance and approval.

\subsection{Data Analysis}

The study employed weighted mean (WM) in calculating the central tendencies of the various practices. According to (Hanke and Reitsch, 1991), weighted mean as a measure of central tendency assigns more weight to some data values than others. Weighted means for corrupt procurement practices were calculated using (Hanke and Reitsch, 1991) formula below.

$$
\overline{\mathrm{X}}_{\mathrm{w}}=\frac{\sum_{\mathrm{i}=1}^{\mathrm{n}} \mathrm{w}_{\mathrm{i}} \mathrm{Xi}_{\mathrm{i}}}{\sum_{\mathrm{i}=1}^{\mathrm{n}} \mathrm{w}_{\mathrm{i}}}
$$

Where:

$\overline{\mathrm{X}}_{\mathrm{w}}=$ weighted mean

$\mathrm{X}_{\mathrm{i}}=$ data value to be averaged

$\mathrm{w}_{\mathrm{i}}=$ weights applied to the $\mathrm{X}$ value

The calculated weighted means were used to rank the various corrupt procurement practices to determine which of the practices respondents' perceived to be more corrupt.

\subsection{Corrupt Public Procurement Practices}

Table 1 shows the rankings of the various corrupt procurement practices. Approval and certification is a very vital exercise in contract management. Respondents viewed certifying works which do not meet stated specification as the highest corrupt practice. The practice recorded a (WM) of (4.50). It is perceived that some consultants on government projects are gradually loosing track of their responsibilities. For many of them, their handiworks point to professional incompetence. This is evident on a number of completed projects. This professional ineptitude has brought about huge loses to the State and institutions, and deprived the country from enjoying the utmost benefits for initiating such projects. Unfortunately, it appears this professional ineptness is not going to stop anytime soon because of unnecessary political interference on State awarded projects. Not until professionals stand up to political figures to exercise their ethical rights, procurement processes will continue to suffer.

Demanding money, lunch or anything of value from firms before releasing payment certificates is a common practice which is fast becoming a norm in Ghana. This attitude was ranked the second most corrupt procurement practice with a (WM) of (4.39). Contractors and suppliers sometimes have to go through a lot of ordeals before payment certificates are released. These certificates are deliberately delayed because of the self-centered interest of officers in public institutions and sometimes signatories. Firms who want their payment certificates released to them more often than not have to pay to take their certificates. This behaviour is fast becoming a hindrance to genuine businesses and is creating a bad picture for State institutions.

Concealment of vital information during procurement auditing or reporting is real in public institutions. The detection of flaws can be deceptive because of the advent of technology. Concealment is a fraudulent practice. The U.S. General Services and Administration (GSA), (2012) defines "fraud as the misrepresentation of the truth or concealment of a material fact that is intended to induce another to act to his or her detriment". Covering up during procurement reporting was identified to be the third corrupt practice with a (WM) of (4.37). To identify any form of procurement cover-up during reporting requires experience and highly trained skilled manpower. The onus lies on public institutions to set up effective internal and external auditing systems to uncover any wrongdoings during procurement processes.

Exploitation of procurement laws, rules and regulations can come in various forms. A process can be exploited to favour a particular firm at the expense of others to secure a gain. The practice can affect project completion and influence service delivery. The study identified exploitation of weaknesses in law and regulations governing procurement; and procurement officer's firm competing with other firms for the same jobs as the fourth corrupt procurement practice with a (WM) of (4.24). One practice that is killing many firms in Ghana is conflict of interest. Many officials who have been employed by the State to oversee government procurement own firms who are into the business of their profession and more often than not award contracts to their firms. This practice kills competition and with time firms lose interest in institutional tender offers. In Ghana, where payments by government to contractors and suppliers are repeatedly done in phases, officials prepare payment certificates to favour their firms so they can receive their payments before other firms. This practice has partly resulted in the number of shoddy jobs that are delivered. This is because people employed by the State toseek its interest and set the rules and guidelines supervise projects undertaken by their firms. Where such a thing exists, every project executed under such pretense will pass all approval criteria. This practice is a serious conspiracy in government procurement which will need competent professionals to detect and flush them out.

Favouritism violates the principle of procurement. Many officers in State institutions lean towards certain firms because of the benefit they will derive from them. Where such ones are also in competition, they will do everything in their 
power to ensure their success. Some public officers go to the extent of leaking information to firms to create imbalance in competition. The practice can have serious consequences for project delivery and bring about distortions in project allocation. Generous treatment given to some firms at the expense of others was ranked the sixth most corrupt procurement practice with a (WM) of (4.23) while gifts given or received during procurement processes took the seventh spot with a (WM) of (4.17). There is no distinction between bribery and act of generosity in Ghana. Firms offer gifts to procurement officers on many occasions just to secure interest but the interesting thing is that, usually such gifts are interpreted to be act of goodwill. Firms are profit making establishment and will do anything they could to secure an interest. A gift offered by a firm can make an impression and change a major procurement decision in favour of that firm. Solicitation of gifts by officials from firms has become a ritual and professionals do this without shame. This is a practice which will continue to persist because public procurement entities lack comprehensive professional code of ethics.

Respondents ranked subordinates receiving instructions from principal officers to take action not in line with procurement principles and regulations; and tender rigging and collusion by contractors as the eighth corrupt procurement practice with a (WM) of (4.14). It is not wrong for a subordinate to take instructions or orders from a superior officer because that is the structure in every organized institution but by this structure many middle and lower ranked public officers have their rights to decision making violated. They receive orders to take actions that contravene enshrined norms and principles of their engagement. Though this management style helps to maintain order, it has also created a lot of problems in institutions because top officers often overstep their boundaries and violate the rights of others. Conspiracies are carefully plotted schemes between firms, firms and agents in public institutions to take undue advantage of State purse. They come in one form or the other. The essence of the conspiracies that take place among firms is to ensure that favoured firms win public contracts (Campos and Pradhan, 2007). Firms organize such collusions very well without any traces and create the impression that tenders went through a competitive process (Chowdhury, 2008). Conspiracies in public procurement will be hard to accept in the Ghanaian environment but they exist. The Criminal Code (Amendment) Act 2003. s.23(1) defines conspiracy as any agreement between two or more persons acting with a common interest of committing or abetting crime. The bottom line for conspiring is for personal gain.

In procurement, contracts are supposed to be awarded to firms who truly deserve such awards but the reverse is sometimes the case in Ghana. Politicians and superior officers by their actions can change a professional decision. Contracts are habitually awarded to firms who truly do not deserve such awards. Awarding contracts to firms because of instructions from a superior officer was ranked tenth by respondents with a (WM) of (4.13). This practice obstructs the principle of fairness and non-discrimination.

A lot of socially harmful practices sometimes manifest in public procurement. Some of these practices are criminal. Pulling out vital documents from submitted tenders of firms whose inclusion threaten the stance of favoured firms and secretly calling favoured firms to correct their tenders is a criminal act. These two acts were ranked eleventh with a (WM) of (4.11).The Criminal Code (Amendment) Act 2003. s.1. says a "crime is any act punishable by death or imprisonment or fine." These two acts are criminal and socially harmful to the image and wellbeing of State institutions. They destroy and deprive capable and genuine firms. Though, these two practices would be hard to believe by many professionals and stakeholders, nevertheless they occasionally happen.

Failure to take into proper consideration of facts and laws relating to procurement was ranked the thirteenth corrupt practice with a (WM) of (4.09). This can be done intentionally with the aim of favouring a particular firm. Procurement entities dividing procurement orders into parts or lower the value to stay below the threshold beyond which competitive tendering is required was on the other hand ranked fourteenth with a (WM) of (4.03). The Public Procurement Act 2003. s.21(5). states that "a procurement entity shall not divide a procurement order into parts or lower the value of a procurement order to avoid the application of the procedures for public procurement in this Act." Even though this is a criminal act, it has become the practice of some public institutions.

\begin{tabular}{|c|c|c|}
\hline Corrupt Procurement Practices & Weighted Mean (WM) & Ranking \\
\hline Certifying works which do not meet stated specification is a corrupt practice & 4.50 & $1^{\text {st }}$ \\
\hline $\begin{array}{l}\text { Demanding money, lunch or anything of value from a firm before releasing a } \\
\text { payment certificate is a corrupt practice }\end{array}$ & 4.39 & $2^{\text {nd }}$ \\
\hline Covering up during procurement reporting is a corrupt practice & 4.37 & $3^{\text {rd }}$ \\
\hline $\begin{array}{c}\text { Exploiting weaknesses in laws and regulations governing procurement is a } \\
\text { corrupt practice }\end{array}$ & 4.24 & $4^{\text {th }}$ \\
\hline $\begin{array}{l}\text { Where a procurement officer's company is also competing for the same job or } \\
\text { contract is a corrupt practice }\end{array}$ & 4.24 & $4^{\text {th }}$ \\
\hline $\begin{array}{l}\text { Generous treatment given to one firm at the expense of others is a corrupt } \\
\text { practice }\end{array}$ & 4.23 & $6^{\text {th }}$ \\
\hline Gifts given or received during the procurement process is a corrupt practice & 4.17 & $7^{\text {th }}$ \\
\hline $\begin{array}{l}\text { A procurement officer instructing a subordinate to take any action not in line } \\
\text { with procurement principles and regulations is a corrupt practice }\end{array}$ & 4.14 & $8^{\text {th }}$ \\
\hline Tender rigging and collusion by contractors is a corrupt practice & 4.14 & $8^{\text {th }}$ \\
\hline $\begin{array}{c}\text { Awarding a contract to a firm because of an instruction from a superior is a } \\
\text { corrupt practice }\end{array}$ & 4.13 & $10^{\text {th }}$ \\
\hline $\begin{array}{c}\text { Pulling out vital documents from submitted tenders of firms whose inclusion } \\
\text { threatens the stance of a favoured firm is a corrupt practice }\end{array}$ & 4.11 & $11^{\text {th }}$ \\
\hline
\end{tabular}




\begin{tabular}{|c|c|c|}
\hline Corrupt Procurement Practices & Weighted Mean (WM) & Ranking \\
\hline $\begin{array}{l}\text { Secretly calling a favoured firm to do correction in his tender is a corrupt } \\
\text { practice }\end{array}$ & 4.11 & $11^{\text {th }}$ \\
\hline $\begin{array}{c}\text { Failure to take into proper consideration of facts and law relating to } \\
\text { procurement is a corrupt practice }\end{array}$ & 4.09 & $13^{\text {th }}$ \\
\hline $\begin{array}{c}\text { Procurement entities dividing procurement orders into parts or lower the } \\
\text { value to stay below the threshold beyond which competitive tendering is } \\
\text { required is a corrupt practice }\end{array}$ & 4.03 & $14^{\text {th }}$ \\
\hline Certifying works which are not properly executed is a corrupt practice & 3.96 & $15^{\text {th }}$ \\
\hline $\begin{array}{l}\text { Practices that undermine the efficiency, credibility and predictability of the } \\
\text { budget execution is a corrupt practice }\end{array}$ & 3.96 & $15^{\text {th }}$ \\
\hline $\begin{array}{c}\text { A clash between a procurement officer's public or organizational interest and } \\
\text { private interest where his private interest overrides his public or } \\
\text { organizational interest is a corrupt practice }\end{array}$ & 3.89 & $17^{\text {th }}$ \\
\hline $\begin{array}{l}\text { Solicitation of anything of value from a firm during the procurement process } \\
\text { by a procurement officer is a corrupt practice }\end{array}$ & 3.87 & $18^{\text {th }}$ \\
\hline $\begin{array}{l}\text { Accepting goods with discrepancies between product's description or normal } \\
\text { appearance and actual appearance is a corrupt practice }\end{array}$ & 3.86 & $19^{\text {th }}$ \\
\hline Adopting unreasonable pre-qualification procedures is a corrupt practice & 3.85 & $20^{\text {th }}$ \\
\hline $\begin{array}{l}\text { Awarding contracts directly to firms without any justification is a corrupt } \\
\text { practice }\end{array}$ & 3.85 & $20^{\text {th }}$ \\
\hline $\begin{array}{c}\text { Amending criteria set in request for tenders to favour a particular firm is a } \\
\text { corrupt practice }\end{array}$ & 3.80 & $22^{\text {nd }}$ \\
\hline $\begin{array}{c}\text { Unreasonable departure from the processes and procedures governing } \\
\text { procurement is a corrupt practice }\end{array}$ & 3.73 & $23^{\text {rd }}$ \\
\hline Supplying favoured firm with relevant information is a corrupt practice & 3.68 & $24^{\text {th }}$ \\
\hline Narrowing of contract specifications to a particular firm is a corrupt practice & 3.64 & $25^{\text {th }}$ \\
\hline $\begin{array}{l}\text { Receiving tender documents when it is past the submission time is a corrupt } \\
\text { practice }\end{array}$ & 3.64 & $25^{\text {th }}$ \\
\hline $\begin{array}{l}\text { Entities providing structures and systems which serve as barriers to entry is a } \\
\text { corrupt practice }\end{array}$ & 3.55 & $27^{\text {th }}$ \\
\hline $\begin{array}{l}\text { Unexplained variations which increase the scope of works and contract price } \\
\text { is a corrupt practice }\end{array}$ & 3.55 & $27^{\text {th }}$ \\
\hline $\begin{array}{l}\text { Extension of submission deadline so that firms can readjust their offers is a } \\
\text { corrupt practice }\end{array}$ & 3.46 & $29^{\text {th }}$ \\
\hline $\begin{array}{c}\text { Limiting the number of publications for request for tenders is a corrupt } \\
\text { practice }\end{array}$ & 3.32 & $30^{\text {th }}$ \\
\hline
\end{tabular}

Table 1: Corrupt Procurement Practices

\subsection{Analysis of the Critiqued Definition}

Out of the (4) critics who critiqued the new definition, (3) said the definition was appropriate but the remaining (1) disagreed. This makes the definition only 75\% suitable. On the adequacy of the definition, (2) affirmed that the definition adequately represents corrupt procurement practice but (1) opposed. The fourth critic stated that, "the definition only listed corrupt procurement practices." The definition was only found to be $50 \%$ acceptable by the critics. Two critics found the definition to be complete whiles the remaining two disagreed. The two critics who disagreed said the definition did not have all the necessary ingredients to make it complete. One out of the (2) who disagreed said the definition was not complete because "the issue of personal gain was not emphasized." Rating the level of completeness of the definition, (1) critic said it was $100 \%$ complete, another rated it $80 \%$ and the remaining (2) rated it $70 \%$ and $40 \%$ respectively. On the average, the level of completeness of the definition was rated $72.5 \%$. This rating is not bad but the researcher thought some useful and important comments were made which could not be overlooked. On the issue of conciseness of the definition, (2) said the definition was not concise, for (1) the definition was very concise and the remaining (1) stated that the definition "could be more concise." The first critic said the emphasis of the definition of corruption is the issue of personal or private gain or benefit and suggested that the definition would have been more appropriate if it was captured. The researcher thought the call from the critic to emphasize the issue of personal gain was in the right direction because that is the ultimate motive of people who engage in corrupt practices. The second critic said the definition is not as concise as the one provided by the European Bank for Reconstruction and Development (EBRD) and the United Nations Commission on International Trade Law (UNCITRAL). The critic stated that it is more understandable because the researcher tried to capture all the necessary angles or experiences to make the definition suitable for the Ghanaian or the African experience. The researcher believes more emphasis was made extensively on corrupt acts and that made the definition lengthier than the original definition. The third critic stated that the definition was too abstract and too broad to interpret. It was argued that the corrupt practices were not well defined and that can give room for people to escape. The critic said the issue of "personal gain" was not emphasized. The critic further argued that the nature of inducement as provided in the ERBD and UNCITRAL definition makes it more concise. The critic believes 
that the definition does not talk about any action. The critic concluded that the definition was too technical and should therefore be simplified just like the ERBD and UNCITRAL definition to suit the Ghanaian context. The remaining critic had no comment to make on the definition. Based on the comments received, the researcher modified the definition by simplifying it. The intention was to ensure that readers who may not have any procurement background could read and understand. The proposed definition which was sent out for the critiquing exercise defined corrupt procurement practice as "actions that disagree with or defy procurement law and regulations, clash of interest, disregard for certified principles or the disclosure of confidential business information to firms, or the dishonest persuasion or inducement of one party that influences the procurement selection process or contract execution."

\section{Conclusion}

After carefully considering all the comments, criticisms and contributions proffered during the critiquing exercise, the definition was modified and sent back to critics for acceptance and approval. The modified definition was accepted by all the critics. The paper therefore concludes by redefining corrupt public procurement practice as: "the direct or indirect offering, giving, receiving, or soliciting of gifts or bribes, conspiracies among firms, or fraudulent practices that influence the procurement selection process or contract execution for personal gain."

\section{Recommendations}

The paper recommends the formulation of punishments for varied procurement offences for both internal professionals and firms. These punishments should be published by entities for parties to know the consequences of their actions. The punishments designed should be strictly enforced to deter future offenders.

Firms whose practices are found to be corrupt should be reported and sanctioned. Sanctions should range from suspending such firms for some number of years or blacklisting them from all forms of procurement activities. Important decisions of that nature should be published in the papers and circulars with copies sent to all entities to ensure that those firms are not included in any public procurement activity in the country.

Procurement entities must train and resource in-house procurement employees to detect corrupt practices. In doing so, there will be the need to establish an independent internal procurement auditing team to monitor the actions of procurement officers and to scrutinize the practices of firms. It will also be important for the internal auditing team to liaise with outside auditing units to efficiently fight against corrupt practices in procurement.

A comprehensive code of ethics should be designed by entities and State institutions to serve as a blue print to guide procurement operations. This code when designed must be duly enforced to bring some sanity in the procurement profession.

\section{References}

i. Aidt, T.S.(2003).Economic Analysis of Corruption: A Survey. The Economic Journal, 113: 632-652.

ii. Amundsen, I., Sissener, T. \&Søreide, T. (2000). Research on Corruption a Policy Oriented Survey. Norway: Chr. Michelsen Institute (CMI) and Norwegian Institute of International Affairs (NUPI).

iii. Andvig, J., Fjeldstad, O-H., Amundsen, I., Sissener, T. \&Søreide, T. (2001). Corruption a review of contemporary research. Report R 2001:7. [pdf]. Bergen: Chr. Michelsen Institute.

iv. Argandona, A.(2003). Private-to- private corruption. IESE Business School: WP No. 531. [pdf]. Madrid: IESE Business School.

v. Ben-Ner, A. \&Putterman, L.(1999). Economics, values and organisation. New York: Cambridge University Press.

vi. Boswell, C. \& Cannon, S.(2012). Introduction to nursing research: incorporating evidence-based practice (3rd ed.). Burlington: Jones \& Bartlett Learning.

vii. Bunker, R. B. \& Casey, K. M.(2012).Facilitating payments versus bribes: are we sending conflicting ethical signals in accounting education? International Journal of Business and Social Science, 3(8): 47-50.

viii. Burguet, R. \& Perry, M. K.(1999). Bribery and Favoritism by Auctioneers in Sealed Bid Auctions. Available fromhttp://fmwww.bc.edu/RePEc/es2000/1827.pdf [Accessed 2013 August 5].

ix. Campos, J. E. \& Pradhan, S.(2007). The many faces of corruption: tracking vulnerabilities at the sector level. Washington, DC: The International Bank for Reconstruction and Development/World Bank.

x. CIPS (2005). The Definition of Procurement. Available from http://www.cipsa.com.au [Accessed 2013 July 19$].$

xi. Cisar, O. (2003). Strategies for Using Information Technologies for Curbing Public-Sector Corruption: The Case of the Czech Republic (CR). Budapest: Open Society Institute.

xii. Chowdhury, J.(2008). The basics of bid rigging, CUTS C-CIER. India: CUTS International.

xiii. Deloitte(2012). Procurement fraud and corruption: a multi-faceted challenge. Available fromhttp://www.deloitte.com/in[Accessed 2013 July 5].

xiv. Djankov, S., Glaeser, E., La Porta, R., Lopez-De-Silanes, F. \& Shleifer, A. (2003). The new comparative economics. Journal of Comparative Economics, 31(4): 595-619.

xV. EBRD(2010). Procurement policies and rules. UK: European Bank for Reconstruction and Development.

xvi. Farlex(2013). Abuse of Discretion. Available from http://legal dictionary.thefreedictionary.com/Abuse+of+Discretion[Accessed 2013 September 13].

xvii. Frøystad, M., Heggstad, K. K. \&Fjeldstad, O-H.(2010). Linking procurement and political economy. Norway: Chr. MichelsenInstitute.

xviii. Fjeldstad, O-H. (1999). Controlling fiscal corruption: theoretical approaches and illustrations from Tanzania. CMI Working Paper 6:99. Bergen: Chr. Michelsen Institute. 
xix. Gilbert, M.(2011). Contract matters: procurement ethics/business and ethics. New Zealand: Genesis.

xx. Hanke, J. E. \&Reitsch, A. G. (1991). Understanding business statistics. Homewood: Irwin.

xxi. Hardell, L., Walker, M.J., Walhjalt, B., Friedman, L. S. \& Richter, E.D. (2007). Secret ties to industry and conflicting interests in cancer research. American Journal of Industrial Medicine, 50(3): 227-233.

xxii. Harstad, B. \&Svensson, J. (2011). Bribes, lobbying, and development. American Political Science Review, 105(1): 46-63.

xxiii. Heggstad, K., Frøystad, M. \&Isaksen, J.(2010). The basics of integrity in procurement: a guidebook. Bergen: CMI.

xxiv. Hellman, J., Jones, G. \& Kaufmann, D.(2000). Are foreign investors and multinationals engaging in corrupt practices in transition economies? Transition, 11(3-4): 4-7.

xxv. Hui, W. S., Othman, R., Omar, N. H., Rahman, R. A. \&Haron, N. H. (2011). Procurement issues inMalaysia. International Journal of Public Sector Management, 24(6): 567-593.

xxvi. Hyytinen, A., Lundberg, S. \&Toivanen, 0.(2006). Favoritism in public procurement: evidence from Sweden. Helsinki, 21-23 September 2006. Helsinki: IPP.

xxvii. Khalil, F. and Lawarrée, J. and Yun, S. (2010). Bribery vs. extortion: allowing the lesser of two evils. RAND Journal of Economics, 41(1): 179-198.

xxviii. Klitgaard, R.(1988). Controlling corruption. California: University of California Press.

xxix. Kumar, R. (1996). Research methodology: a step-by-step guide for beginners. Australia: Longman.

xxx. Lambsdorff, J. G. \& Frank, B. (2010). Bribing versus gift-giving-An experiment. Journal of Economic Psychology, 31(3): 347-357.

xxxi. Lindsay, P. and Norman, D. A., 1977. Human information processing: an introduction to psychology (2nd ed.). New York: Academic Press.

xxxii. Myint, U.(2000). Corruption: causes, consequences and cures. Asia-Pacific Development Journal, 7(2): 33-58.

xxxiii. Nichols, P. M. (2009). Who Allows Facilitating Payments? Agora without Frontiers, 14(4): 303-323.

xxxiv. Ocheje, D.(2001). Law and social change: a socio-legal analysis of Nigeria's corrupt practices and other related offences Act 2000. Journal of African Law, 45: 173-195.

xxxv. OECD (2007). Bribery in public procurement: methods, actors and counter-measures. Paris: Organisation for Economic Co-operation Development.

xxxvi. Osei-Tutu, E.(2010). Conflict of interest and related corrupt practices in public procurement in Ghana. Ghana: Ghana Institution of Surveyors.

xxxvii. Polit, D. F. \&Beck, C. T.(2004). Nursing research: principles and methods. Philadelphia: Lippincott Williams \& Wilkins.

xxxviii. Public Procurement Act 2003. (s.21). Accra: Republic of Ghana.

xxxix. Reed, Q.(2010). Regulating conflicts of interest in challenging environments: the case of Azerbaijan. U4 ISSUE 2010:2. Bergen: U4 Anti- Corruption Resource Centre.

xl. Rose-Ackerman, S. \&Søreide, T. eds.(2011). International Handbook on the economics of corruption, (Vol. 2.). UK: Edward Elgar Publishing Ltd.

xli. Rose-Ackerman, S.(1999). Corruption and government: causes, consequences, and reform. Cambridge: Cambridge University Press.

xlii. Rose-Ackerman, S.(1978). Corruption: A Study in Political Economy. New York: Academic Press.

xliii. Seldadyo, H. \& De Haan, J.(2006). The determinants of corruption: a literature survey and new evidence. Turku, Finland, 20-23 April 2006. Finland: EPCS.

xliv. Smith, R. (2006). Conflict of interest: how money clouds objectivity. Journal of the Royal Society of Medicine, 99(6): 292-297.

xlv. Svensson, J. (2005). Eight questions about corruption.Journal of Economic Perspectives, 19(3): 19-42.

xlvi. Thai, K.V. ed.(2009). International Handbook of Public Procurement. London: CRC Press.

xlvii. The Criminal Code (Amendment) Act 2003. (s.1). Accra: Republic of Ghana.

xlviii. TRACE (2009). Facilitation payments benchmarking survey: TRACE Anti-Bribery Compliance Solutions. Available at:[http://secure.traceinternational.org/data/public/documents/FacilitationPaymentsSurveyReFacil-646221.pdf [Accessed 2013 June 9].

xlix. Transparency International, 2006. Handbook for Curbing Corruption in Public Procurement. Berlin: Transparency International.

l. UNCITRAL, 2008. United Nations Convention against Corruption: Implementing Procurement-Related Aspects. (UNCITRAL,CAC/COSP/2008/CRP.2). Available from http://www.uncitral.org/pdf/english/workinggroups/wg_1/INF.2.pdf[ Accessed2013 July23.[

li. U.S. General Services and Administration, (2012). Office of inspector general procurement fraud handbook. US: GSA.

lii. Wensink, W. \& Maarten de Vet, J.(2013). Identifying and reducing corruption in public procurement in the EU. Brussels: PwC EU Services.

liii. World Bank (1997). Helping countries combat corruption: the role of the World Bank. Washington DC: The World Bank. Available from http://www1.worldbank.org//cor02.htm [Accessed 2013 July 8]. 